\title{
Anterior segment optical coherence tomography in acute anterior uveitis
}

\section{Tomografia de coerência óptica do segmento anterior em uveíte anterior aguda}

\author{
Cristiana Agra ${ }^{1}$, Lydianne Agra ${ }^{1}$, Jeanine Dantas ${ }^{1}$, Tiago Eugênio Faria e Arantes ${ }^{1}$, João Lins de Andrade Neto ${ }^{1}$
}

\begin{abstract}
Purpose: To analyze the corneal thickness and anterior chamber (AC) angle using anterior segment optical coherence tomography (AS-OCT) in patients with acute anterior uveitis (AAU).

Methods: Twenty two patients (24 eyes) were included. All patients underwent complete ophthalmological examination, applanation tonometry and AS-OCT at diagnosis and fifteen days after treatment.

Results: Average corneal thickness before treatment was $564.2 \pm 44.2 \mu \mathrm{m}, 580.0 \pm$ $44.3 \mu \mathrm{m}$ and $580.1 \pm 2.9 \mu \mathrm{m}$, respectively in central, pericentral and paracentral cornea. Fifteen days after treatment a significant decrease of corneal thickness was observed, with $529.5 \pm 33.1 \mu \mathrm{m}(\mathrm{p}=0.0091)$ and $542.6 \pm 33.6 \mu \mathrm{m}(\mathrm{p}=0.0068)$ respectively in central and pericentral cornea; paracentral corneal thickness $(557.8 \pm 35.3 \mu \mathrm{m})$ thinning did not reach statistical significance $(p=0.1253)$. There was no significant change in temporal AC angle between visits, $44.3 \pm 14.4$ degrees before treatment and $44.7 \pm 14.7$ degrees fifteen days after $(p=0.9343)$, and mean intraocular pressure, $10.8 \pm 4.5 \mathrm{mmHg}$ before treatment and $12.3 \pm 3.0 \mathrm{mmHg}$ fifteen days after ( $p=0.1874)$.

Conclusion: In the studied group, AS-OCT detected a decrease of corneal thickness after AAU treatment. Temporal AC angle and intraocular pressure did not change during the studied period.
\end{abstract}

Keywords: Uveitis, anterior/diagnosis; Tomography, optical coherence; Anterior eye segment; Inflammation; Corneal pachymetry

\section{RESUMO}

Objetivo: Analisar a espessura corneal e ângulo da câmara anterior (CA) utilizando a tomografia de coerência óptica de segmento anterior (OCT-SA) em pacientes com uveíte anterior aguda (UAA).

Métodos: Foram selecionados 24 olhos de 22 pacientes com UAA. Todos foram submetidos a exame oftalmológico completo, tonometria de aplanação e OCT-SA na consulta inicial e após 15 dias de início do tratamento.

Resultados: Na visita inicial, as médias da espessura corneal foram de 564,2 $\pm 44,2$ ume $580,0 \pm 44,3 \mu \mathrm{m}$ e 580,1 $\pm 2,9 \mu \mathrm{m}$, respectivamente para as regiões central, pericentrale paracentral. Após 15 dias de tratamento, observou-se redução da espessura para 529,5 $\pm 33,1 \mu \mathrm{m}(p=0,0091)$ e 542,6 $\pm 33,6 \mu \mathrm{m}(p=0,0068)$, respectivamente para a córnea central e pericentral; e um valor de 557,8 $\pm 35,3 \mu \mathrm{m}$ para a região paracentral, porém para um $p$ não significante $(p=0,1253)$. Não foi observada mudança estatisticamente significante nos valores da porção temporal do ângulo da $C A ; 44,3 \pm 14,4$ graus na visita inicial e de $44,7 \pm 14,7$ graus após 15 dias de tratamento $(p=0,9343)$ e na média das pressões intraoculares (PIO), 10,8 $\pm 4,5 \mathrm{mmHg}$ na visita inicial e 12,3 $\pm 3,0 \mathrm{mmHg}$ após tratamento $(p=0,1874)$.

Conclusão: No grupo estudado, obteve-se uma redução dos valores da espessura corneal após início do tratamento da UAA. Os valores da porção temporal do ângulo da CA e PIO não sofreram mudanças significantes.

Descritores: Uveíte anterior/diagnóstico; Tomografia de coerência óptica; Segmento anterior do olho; Inflamação; Paquimetria corneana

\section{INTRODUCTION}

Acute anterior uveitis (AAU) is the most common type of intraocular inflammation, with varying incidence reported worldwide ${ }^{(1)}$. Although, in general, it is a smaller threat to vision than posterior uveitis, it is an important cause of blindness and ocular morbidity in Brazil ${ }^{(1,2)}$.

Most often, AAU manifests with varying degrees of pain and ocular hyperemia, visual blurring, and inflammatory cells in the anterior chamber (AC). In severe cases, it can be associated with increased intraocular pressure $(\mathrm{IOP})^{(1)}$. Open-angle or closed-angle glaucoma have been described in $20 \%$ uveitis cases ${ }^{(3)}$, and ocular hypertension is considered an important complication of uveitis, particularly when it involves the anterior ocular segment ${ }^{(4)}$.

The corneal involvement during uveitis remains understudied, although the cornea is probably a target of intraocular inflammation ${ }^{(2)}$. Inflammation of the anterior segment causes changes in the endothelium that, if severe, can compromise the integrity of the cornea; these changes have been observed in some studies using specular microscopy ${ }^{(5)}$. Some authors have proposed that corneal thickness is an indicator of endothelial function and suggested that this response can be clinically assessed via central pachymetry measurement ${ }^{(6)}$.

Optical coherence tomography (OCT) is a noninvasive and noncontact method that provides information on corneal disorders that cannot be obtained by biomicroscopic examination (7). In addition, it is a high-resolution imaging method for the determination of the AC angle ${ }^{(8)}$.

Therefore, this study aimed to analyze the corneal thickness and AC angle using Anterior Segment OCT (AS-OCT) in patients with AAU.

\section{METHODS}

This prospective study involved 22 patients (24 eyes) with AAU admitted to the emergency service of Fundação Altino Ventura de Recife-Pernambuco (FAV); patients with chronic uveitis, panuveites, intermediate and posterior uveitis, other ocular comorbidities, or previous history of eye surgery were excluded. The criteria defined by the Standardization of Uveitis Nomenclature (SUN) Working Group were 
used to select patients, and eye samples with scores ranging from +1 to +4 were included ${ }^{(9)}$. The disease was diagnosed on the basis of clinical history and eye examination.

The subjects were invited to undergo the first OCT-SA at the time of the initial emergency visit and to return to the service for the second examination 15 days after treatment initiation. The procedure was performed before dilatation of the pupils in both situations. IOP was measured using Goldmann applanation tonometry on both consultations.

Images of the anterior segment were obtained using the anterior segment module of the RTVue ${ }^{\circledR}$ Fourier-domain system (Optovue, Fremont, California, USA). The central thickness of the cornea and the trabecular temporal angle of $A C$ were measured during the same consultation. During the exam, the central corneal thickness was measured using the pachymetry map obtained with the use of an optional attached lens (CAM-L) $(8 \times 1024$ A-scans). The temporal angle of $A C$ was obtained through the scan of $A C$ angle provided by the same lens CAM-L $(1 \times 1024$ A-scans). The pachymetry map was generated by the system from eight 6-mm-long meridional scans centralized in the pupil. Each 6-mm line consisted of 1.024 axial scans acquired in $0.04 \mathrm{~s}$ and the set of eight meridians was obtained in $0.31 \mathrm{~s}$. Five consecutive sets were obtained in $1.55 \mathrm{~s}$ and the three most consistent were used to calculate corneal power. Thickness was analyzed in three sectors: central area ( $2 \mathrm{~mm}$ central diameter); pericentral area (ring between 2 and $5 \mathrm{~mm}$ ), and paracentral area (ring between 5 and $6 \mathrm{~mm})^{(10)}$.

The Schwalbe line (SL), a visible anatomical structure with good image definition in the sections produced by the system, was considered the reference to measure AC angle. The measure of the angle opening from $S L$ is a method of quantifying $A C$ angle opening in RTVue images. Transverse scans $(6 \times 2 \mathrm{~mm})$ were performed and the temporal portion of AC angle was analyzed ${ }^{(10)}$.

Statistical analysis was performed with the Epi Info (version 7) and the R-cran (version 15) software programs. The results of the quantitative variables were expressed as means \pm standard deviation (SD), whereas the qualitative variables were expressed as absolute and relative frequencies. The Wilcoxon test was used to assess the mean difference, and the level of significance was set at $5 \%$.

The study was approved by the Ethics Committee in Human Research (protocol No. 026/2011). All patients signed an informed consent and received ophthalmological follow-up care.

\section{RESULTS}

Twenty-two patients (24 eyes) participated in the study, including 15 women (68.2\%) and 7 men (31.8\%). The age of the participants ranged between 7 and 72 years (mean $42.8 \pm 20.3$ years). Seventeen patients had the first episode of AAU and 10 patients had recurrent AAU.

The results of the biomicroscopic examination of the anterior segment in the first consultation and 15 days after treatment are shown in Table 1.

Before the initiation of the treatment, the mean central corneal thickness of patients was $564.2 \pm 44.2 \mu \mathrm{m}$; the thickness of the pericentral and paracentral areas were $580.0 \pm 44.3 \mu \mathrm{m}$ and $580.1 \pm 2.9 \mu \mathrm{m}$, respectively. Fifteen days after the initiation of treatment, there was a reduction in corneal thickness. The mean value of the patients' central thickness was $529.5 \pm 33.1 \mu \mathrm{m}$, the pericentral thickness was $542.6 \pm 33.6 \mu \mathrm{m}$, and the paracentral thickness was $557.8 \pm 35.3 \mu \mathrm{m}$. The central and pericentral corneal thickness was higher before the initiation of treatment, $p=0.0091$ and 0.0068 , respectively, whereas the paracentral thickness decreased; however, p was not significant $(p=0.1253)$ (Figure 1).

The mean $\mathrm{AC}$ angles of participants was $44.3^{\circ} \pm 14.4^{\circ}$ and the mean intraocular pressure was $10.8 \pm 4.5 \mathrm{mmHg}$ before treatment. After treatment, the mean $\mathrm{AC}$ angle were $44.7^{\circ} \pm 14.7^{\circ}$ and the mean intraocular pressure was $12.3 \pm 3.0 \mathrm{mmHg}$ (Figure 2). Tonometry values were not obtained for two patients because of their difficulty in participating in the study. No patient had IOP of $>21 \mathrm{mmHg}$. The values of AC angle and IOP between the assessed periods were not significantly different ( $p=0.9343$ and 0.1874 , respectively) (Table 2).

\section{DISCUSSION}

In general, anterior uveitis (AU) is associated with fewer sequelae than inflammation of the posterior segment, especially if it is treated early. However, its potential for severe ocular consequences is probably underestimated if recurrent or poorly managed ${ }^{(1)}$.

Endothelial anomalies have been observed in cases of AU and posterior uveitis. Some authors have studied these changes in several corneal disorders and uveitis, using specular microscopy ${ }^{(2)}$. It is well known that endothelial anomalies occur in uveitis ${ }^{(5)}$.

Polymorphism and polymegathism of the endothelial cells can occur in $\mathrm{AU}^{(5,7)}$. Studies using specular microscopy have demonstra-

Table 1. Results of the anterior segment biomicroscopy of the 24 eyes with acute anterior uveitis subjected to AS-OCT

\begin{tabular}{lcc}
\hline & Initial visit & $\mathbf{1 5}^{\text {th }}$ day of treatment \\
\hline Results & $\mathbf{n}(\%)$ & $\mathbf{n}(\%)$ \\
\hline Keratic precipitates & $6(25.0)$ & $1(4.2)$ \\
Fibrin membrane & $4(16.7)$ & $0(0.0)$ \\
Posterior synechiae & $7(29.2)$ & $3(12.5)$ \\
Iris pigments in the lens & $5(20.8)$ & $4(16.7)$ \\
\hline Anterior chamber cell core & $\mathbf{n ( \% )}$ & $\mathbf{n}(\%)$ \\
\hline+1 & $4(16.7)$ & $17(70.8)$ \\
+2 & $11(45.8)$ & $4(16.7)$ \\
+3 & $5(20.8)$ & $2(8.3)$ \\
+4 & $4(16.7)$ & $1(4.2)$ \\
\hline
\end{tabular}

A
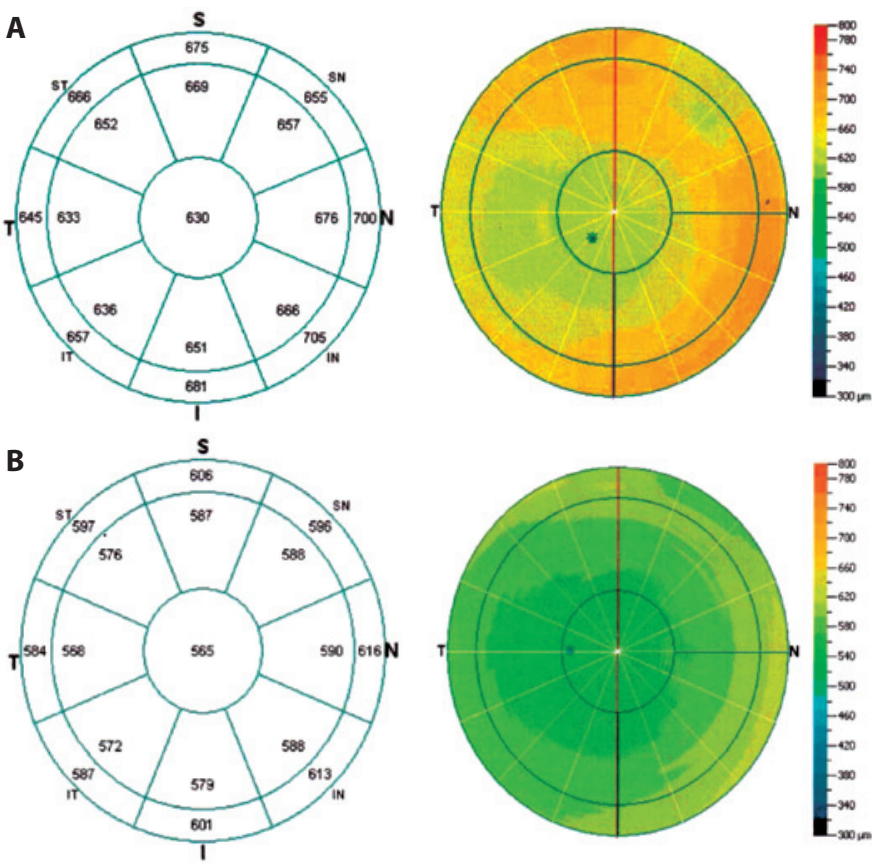

Figure 1. A) Pachymetry map before the start of the treatment. B) Pachymetry map 15 days after the start of the treatment. 


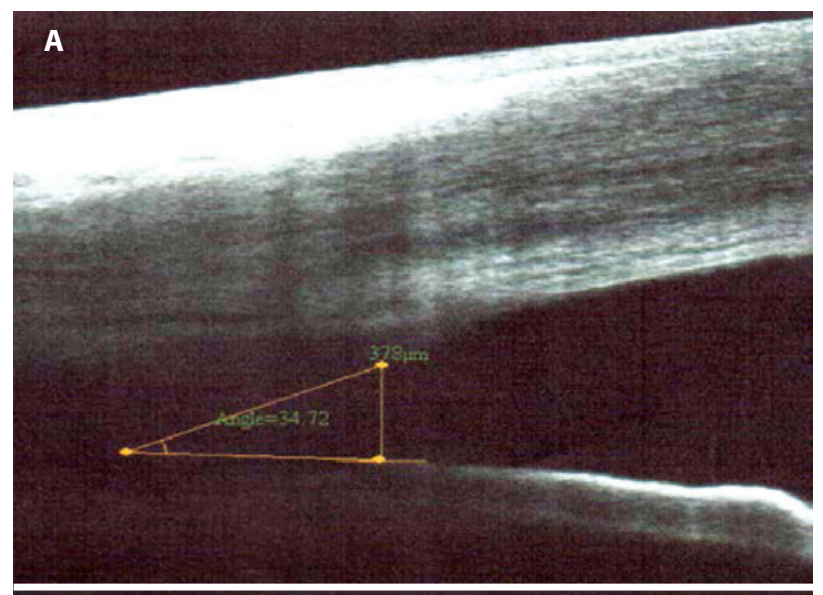

B

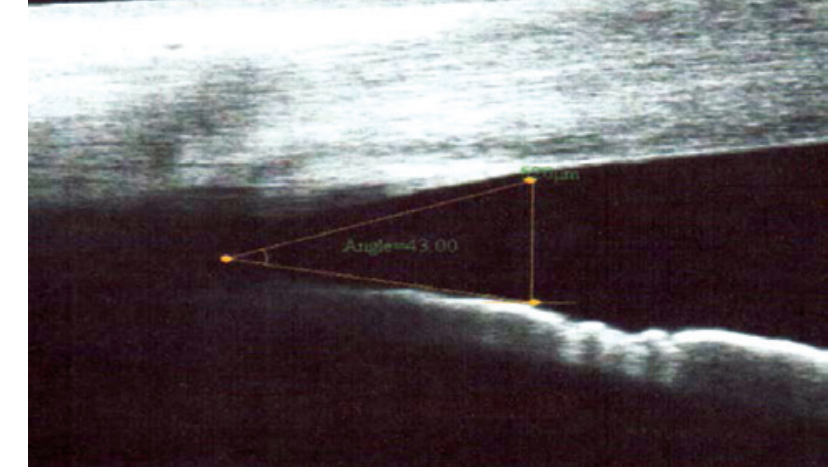

Figure 2. A) Temporal portion of the $A C$ angle viewed on SA-OC before the start of the treatment. B) Temporal portion of AC 15 days after the start of the treatment.

Table 2. Comparison between the variables observed on AS-OCT regarding the assessment period

\begin{tabular}{lccc}
\hline & \multicolumn{2}{c}{$\begin{array}{c}\text { Assessment period } \\
\text { (Mean } \pm \text { SD) }\end{array}$} & $\begin{array}{c}\text { p } \\
\text { variables }\end{array}$ \\
\cline { 2 - 3 } & \multicolumn{2}{c}{ Pretreatment } & Post-treatment \\
\hline Central pachymetry $(\mu \mathrm{m})$ & $564.2 \pm 44.2$ & $529.50 \pm 33.1$ & 0.0091 \\
Pericentral pachymetry $(\mu \mathrm{m})$ & $580.0 \pm 44.3$ & $542.59 \pm 33.6$ & 0.0068 \\
Paracentral pachymetry $(\mu \mathrm{m})$ & $580.1 \pm 2.9$ & $557.77 \pm 35.3$ & 0.1253 \\
Angle of the anterior chamber $\left(^{\circ}\right)$ & $44.3 \pm 14.4$ & $44.73 \pm 14.7$ & 0.9343 \\
Intraocular pressure $(\mathrm{mmHg})$ & $10.8 \pm 4.5$ & $12.27 \pm 3.0$ & 0.1874 \\
\hline
\end{tabular}

ted endothelial changes induced by inflammation, which include defects in the endothelium associated to the deposition of precipitates on the posterior surface of the cornea and other defects similar to guttata and not associated with the precipitates. Moreover, in most patients, these alterations tended to disappear completely, together with other signs of acute inflammation, without changes in cell count, and were significantly correlated with the increase in corneal thickness during the inflammatory period of the disease ${ }^{(11)}$. Despite these anomalies, the majority of cases of uveitis did not progress to permanent corneal decompensation ${ }^{(5,6)}$ and pachymetry values returned to normal by the end of the inflammatory $\operatorname{crisis}^{(6)}$.
In a study conducted in patients with Behçet's disease, the mean central pachymetry in patients with active disease was significantly higher than that in patients with inactive disease and in the control group. Some mechanisms have been proposed to explain the negative effect of the inflammatory process on the endothelium. In this sense, several inflammatory mediators and cytokines have been found in the aqueous humor and cornea during inflammation and are probably responsible for cellular damage ${ }^{(6)}$.

The patients in this study exhibited a significant reduction in mean central pachymetry between the initial period of the disease and following the control of ocular inflammation $(564.2 \pm 44.3 \mu \mathrm{m}$ to $529.50 \pm 33.1 \mu \mathrm{m}$, respectively). We would like to point out that no patient had edema of the cornea on clinical examination.

The patients in this study did not exhibit a significant change in IOP during the disease; however, inflammation of the anterior segment, particularly in severe cases, can occur with the increase in $\mathrm{IP}^{(1)}$. We observed an increase in pachymetry in the sample during the uveitis crisis. Thickening of the cornea caused by edema can lead to underestimated IOP measurement by Goldmann applanation tonometry ${ }^{(12,13)}$, which may interfere with the established approach.

In this study, the mean temporal AC angle was within normal values and the difference between the pretreatment and post-treatment periods was not statistically significant, probably because most of these patients exhibited mild to moderate ocular inflammation, with low frequency of posterior synechiae. In addition, there were few cases of recurrent uveitis, and without sequelae from previous episodes.

\section{CONCLUSIONS}

Anterior segment optical tomography detected a reduction in the corneal thickness 15 days after initiation of the acute anterior uveitis treatment. No alterations in the anterior chamber angle were observed.

\section{REFERENCES}

1. Agrawal RV, Murthy S, Sangwan V, Biswas J. Current approach in diagnosis and management of anterior uveitis. Indian J Ophthalmol. 2010;58(1):11-9. Review.

2. Oliveira F, Motta AC, Muccioli C. [Corneal specular microscopy in infectious and noninfectious uveitis]. Arq Bras Oftalmol. 2009:72(4):457-61. Portuguese.

3. Bodh SA, Kumar V, Raina UK, Ghosh B, Thakar M. Inflammatory glaucoma. Oman J Ophthalmol. 2011;4(1):3-9.

4. Pogorzalek N, de Monchy I, Gendron G, Labetoulle M. [Hypertony and uveitis: 103 cases of uveitis]. J Fr Ophtalmol. 2011;34(3):157-63. French.

5. Pillai CT, Dua HS, Azuara-Blanco A, Sarhan AR. Evaluation of corneal endothelium and keratic precipitates by specular microscopy in anterior uveitis. Br J Ophthalmol. 2000; 84(12):1367-71

6. Ozdamar Y, Berker N, Ertugrul G, Gurlevik U, Karakaya J, Ozkan SS. Is there a change of corneal thickness in uveitis with Behçet disease? Cornea. 2010;29(11):1265-7.

7. Hirano K, Ito Y, Suzuki T, Kojima T, Kachi S, Miyake Y. Optical coherence tomography for the noninvasive evaluation of the cornea. Cornea. 2001;20(3):281-9.

8. Khor WB, Sakata LM, Friedman DS, Narayanaswamy A, Lavanya R, Perera SA, et al. Evaluation of scanning protocols for imaging the anterior chamber angle with anterior segment-optical coherence tomography. J Glaucoma. 2010;19(6):365-8.

9. Jabs DA, Nussenblatt RB, Rosenbaum JT; Standardization of Uveitis Nomenclature (SUN) Working Group. Standardization of uveitis nomenclature for reporting clinical data. Results of the First International Workshop. Am J Ophthalmol. 2005;140(3):509-16. Review.

10. Huang D. RTVue fourier-domain optical coherence tomography primer series. Vol. II Cornea and anterior segment. Fremont: Optovue Inc; 2009.

11. Olsen T. Transient changes in specular appearance of the corneal endothelium and in corneal thickness during anterior uveitis. Acta Ophthalmol (Copenh). 1981;59(1):100-9.

12. Heinz C, Taneri S, Roesel M, Heiligenhaus A. Influence of corneal thickness changes during active uveitis on Goldmann applanation and dynamic contour tonometry. Ophthalmic Res. 2012;48(1):38-42.

13. Ehlers N, Bramsen T, Sperling S. Applanation tonometry and central corneal thickness. Acta Ophthalmol (Copenh). 1975;53(1):34-43. 